\title{
SAIRAUSKÄSITYKSET, ELÄMÄNHALLINTA JA SOPEUTUMISVALMENNUSTA KOSKEVAT ODOTUKSET
}

\section{Johdanto}

Sopeutumisvalmennus on kuntoutusmuoto, jonka avulla pyritään tukemaan kuntoutujaa vamman tai pitkäaikaisen sairauden hallinnassa. Sen tavoitteena on, että kuntoutuja ja hänen läheisensä pystyvät jatkamaan mahdollisimman itsenäistä ja täysipainoista elämää sairauden tai vamman muuttamassa arjessaan ja osallistumaan yhteisöjen ja yhteiskunnan toimintaan. Sopeutumisvalmennuksen aikana kuntoutuja etsii keinoja voimavarojensa vahvistumiseen ja elämäntilanteensa hallintaan. Hän saa tietoa vammasta tai sairaudesta ja sen hoidosta, ja häntä tuetaan ohjauksen, neuvonnan ja valmennuksen keinoin sairauteen tai vammaan liittyvien pelkojen tai rajoitteiden käsittelyssä. Sopeutumisvalmennuksen aikana kuntoutujalla ja hänen perheellään on myös mahdollisuus vertaistuen saamiseen ja antamiseen. Samalla tuetaan heidän osallistumistaan heille tärkeiden yhteisöjen toimintaan. (Rissanen ym. 2008, Nylen ym. 2009, Vilkkumaa 2014, Järvikoski Et Härkäpää 2014.)

Usein sopeutumisvalmennukseen osallistutaan sellaisessa muutosvaiheessa, jossa kaivataan tietoa omasta sairaudesta tai vammasta ja pyritään muodostamaan realistinen kuva omasta elämäntilanteesta ja tulevaisuuden mahdollisuuksista. Yksilöllisillä sairauskäsityksillä tarkoitetaan sitä, kuinka ihminen ym- märtää ja tulkitsee sairauttaan tai vammaansa sekä siihen liittyviä haittoja ja rajoituksia. Leventhalin ym:iden (1992a,b) itsesäätelymallin lähtökohtana on ajatus, että ihminen luo henkilökohtaisen käsityksen sairaudestaan tai vammastaan tietojensa, kokemustensa ja kulttuuristen narratiivien pohjalta ja säätelee omaa toimintaansa sen perusteella. Tilanteen prosessointi tapahtuu sekä kognitiivisella että emotionaalisella, tunnereaktioiden tasolla.

Sairauskäsitykset vaikuttavat osaltaan siihen, millaisia keinoja ihminen käyttää pyrkiessään selviytymään sairautensa kanssa. Myönteisten sairauskäsitysten on todettu olevan yhteydessä muun muassa parempaan sairaudesta toipumiseen, työssä oloon ja nopeampaan työhön paluuseen (esim. Broadbent ym. 2006, Hoving ym. 2010), kun taas kielteiset sairauskäsitykset puolestaan ennakoivat psyykkistä rasittuneisuutta, masennusta ja ahdistuneisuutta (esim. Morgan ym. 2014). Esimerkiksi syöpää sairastavien sairauskäsitysten käsittelyä ja asiakkaan tilanteeseen sopivaa informaatiota on pidetty tärkeänä osana masennus- ja ahdistusoireiden ehkäisyä (Morgan ym. 2014) ja elämänlaadun parantamista (Husson ym. 2013, Kaptein ym. 2015). Myös syövän uusiutumista koskevien pelkojen lievittämisessä on pidetty tärkeänä sairauskäsityksiin vaikuttamista oikean tiedon avulla (Corter ym. 2013). Fibromyalgiaa sairastavien myönteiset sairauskäsitykset 
näyttävät olevan yhteydessä kuntoutuksen parempiin tuloksiin, ja siksi tutkijat suosittelevat, että sairauskäsityksiä koskeva keskustelu pyritään integroimaan osaksi kuntoutusta mahdollisimman varhaisessa vaiheessa (Glattacker ym. 2010). Myös diabetesta sairastavien sairauskäsitysten ja hoitoa koskevien odotusten käsittely voi tukea hoitotulosten saavuttamista ja elämänlaatua (Broadbent ym. 2011).

Sopeutumisvalmennuksen aikana kuntoutujalla on mahdollisuus saada tukea oman tilanteensa tulkintaan ja selviytymiskeinojen etsimiseen sekä asiantuntijoilta että vertaisilta. Terveydenhuollon ja kuntoutuksen ammattilaisten antama tieto ja tuki on tärkeää, mutta sen hyödyntäminen voi stressaavassa tilanteessa olla vaikeaa (vrt. Moos \& Holahan 2003). Vertaisryhmän antaman tuen erityispiirteitä ovat tuen vastavuoroisuus, yhteisyyden tunne ja mahdollisuus etsiä ratkaisuja yhteisiin haasteisiin. Vertaistuki voi osaltaan auttaa kuntoutujaa oman tilanteen realistiseen arviointiin. Se voi vaikuttaa kuntoutujan sairautta tai vammaisuutta koskeviin käsityksiin mutta myös hänen käsityksiinsä itsestään, identiteetistään ja omista mahdollisuuksistaan. (Dunn ym. 2003, Tang ym. 2011, Ussher ym. 2006.)

Sopeutumisvalmennuksen oletettuja merkityksiä tarkastellaan usein myös valtaistumisen (empowerment) käsitteen avulla (esim. Homan-Helenius 2005). Valtaistumisen psykologisella mallilla tarkoitetaan yksilöllistä prosessia, jonka aikana ihmisen tiedot ja kriittinen tietoisuus omasta tilanteestaan lisääntyvät ja samalla itseluottamus ja hallinnan tunne vahvistuvat, ja valtaistumisen $\mathrm{ku}-$ luttajamallilla prosessia, jossa kuntoutujan mahdollisuudet henkilökohtaisiin valintoihin, palvelujensa suunnitteluun ja niitä koskevaan päätöksentekoon vahvistuvat (Masterson \& Owen 2006). Vertaisryhmien tarjoamaa vastavuoroista tukea on pidetty tärkeänä tekijänä valtaistumisprosessissa (Ussher ym. 2006). Laadullisissa tutkimuksissa vertaisryhmien merkitys on esimerkiksi syöpää tai fibromyalgiaa sairastavilla näkynyt itseluottamuksen lisääntymisenä ja hallinnan tunteena suhteessa itseen, sairauden kanssa elämiseen ja terveydenhuollon kanssa asioimiseen (Sallinen ym. 2011, Ussher ym. 2006, van UdenKraan ym. 2008). Vertaistukeen voi kuitenkin liittyä myös kielteisiä kokemuksia (Embuldeniya ym. 2013).

Hallinnan tunne tarkoittaa ihmisen kokemusta siitä, että hän pystyy toiminnallaan vaikuttamaan omaan elämäänsä ja sen tapahtumiin (Pearlin \&t Schooler 1978). Se on psykososiaalinen resurssi, joka vähentää kuormittavien elämäntilanteiden kielteisiä vaikutuksia psyykkiseen hyvinvointiin; tutkimusten mukaan se on käänteisessä yhteydessä psyykkiseen rasittuneisuuteen (Avison Ct Cairney 2003, Pudrovska ym. 2005, Pearlin Et Bierman 2013). Hallinnan tunteeseen vaikuttavat monet henkilökohtaiset ja rakenteelliset tekijät ihmisen elämänprosessin aikana (Aneshensel 2015). Väestötutkimuksessa pitkäaikainen sairaus tai vammaisuus on yhteydessä heikentyneeseen hallinnan tunteeseen (esim. Schieman \&t Turner 1998). Reaktiot ovat kuitenkin yksilöllisiä. Vammaisuus voi toimia myös eksistentiaalisena haasteena, joka virittää uusia oppimiskokemuksia ja voi niiden myötä vahvistaa henkilökohtaista hallintaa (Pudrovska 2010).

Sopeutumisvalmennukseen tulevilla on monenlaisia tarpeita, kurssin sisältöön kohdistuvia toiveita sekä kurssin vaikutuksia koskevia odotuksia. Asiakkaiden koetut tarpeet ovat usein toisenlaisia kuin ammattilaisten tekemät tarvearviot, ja niiden huomioon ottaminen on tärkeää tavoiteltavien tulosten kannalta (Kersten ym. 2000, Asadi-Lari ym. 2004, Beran 2015). Kuntoutujien kokemien tarpeiden selvittäminen avaa keskusteluväylän asiakkaan ja asiantuntijoiden välille, ja niiden tunteminen on välttämätöntä palveluja kehitettäessä. Toiset tarpeet ovat välittömämmin yhteydessä asiakkaan elämisen laatuun kuin toiset (Wen \&t Gustafson 2004). Puumalaisen ym:iden (2014) tutkimuksessa lääkinnälliseen kuntoutukseen osallistuneiden odotukset koskivat sekä fyysisiä, psyykkisiä ja psykososiaalisia toimintoja että yleistä selviytymistä ja elämänhallintaa. Voidaan olettaa, että sekä sosiaalisilla tekijöillä, sairauskäsityksillä 
että tulevaisuuden ennakoinnilla on vaikutusta myös sopeutumisvalmennusta koskeviin odotuksiin.

\section{Tutkimuksen tausta ja tarkoitus}

Tämä tutkimus perustuu sopeutumisvalmennuskurssien seurantatutkimukseen, jonka toteuttajana on Lapin yliopisto ja rahoittajana Kela. Tutkimuksen yleisenä tarkoituksena on selvittää sopeutumisvalmennuksen asemaa osana suomalaista kuntoutustoimintaa ja sen koettuja vaikutuksia. Tutkimuksessa kerättiin lomakekyselyillä ja fokusryhmähaastatteluilla tietoja sopeutumisvalmennukseen osallistuvilta aikuisilta, siihen osallistuvien lasten vanhemmilta ja nuorilta sekä kuntoutuspalvelun tuottajilta. Lasten vanhemmille ennen kuntoutuksen alkua suunnatun kyselyn tuloksia on raportoitu aiemmin (Kippola-Pääkkönen ym. 2016).

Aikuisten sopeutumisvalmennusta koskevassa tiedonkeruussa oli mukana neljä kuntoutuslaitosta, joissa järjestettiin syöpää, fibromyalgiaa ja tyypin 1 diabetesta sairastavien aikuisten kursseja. Kuntoutujille suunnatut lomakekyselyt toteutettiin kurssien alkaessa, niiden päättyessä sekä 5-6 kuukautta kurssien päättymisen jälkeen. Käsillä oleva osatutkimus perustuu sopeutumisvalmennukseen osallistuneille aikuisille kuntoutujille tehtyyn alkukyselyyn.

Tutkimuksessa tarkastellaan sopeutumisvalmennuskursseille saapuvien aikuisten elämäntilannetta ja odotuksia ennen kurssin alkamista. Tavoitteena on selvittää eri kurssiryhmiin osallistuvien kuntoutujien elämäntilannetta, sairauskäsityksiä, hallinnan tunnetta, terveyteen liittyvää valtaistumista ja sopeutumisvalmennukseen liittyviä odotuksia, selvittää, millaiset tekijät ovat yhteydessä kuntoutujien hallinnan tunteeseen ja terveyteen liittyvän valtaistumisen kokemukseen sekä selvittää, millaiset sairauskäsityksiin, hallinnan tunteeseen ja valtaistumiseen liittyvät tekijät ovat yhteydessä sopeutumisvalmennukseen kohdistuviin odotuksiin.

Tutkimussuunnitelma on hyväksytty Kelan eettisessä toimikunnassa.

\section{Aineisto ja menetelmät}

Tutkimukseen kuuluvat syöpäkurssit toteutettiin yhtenä viiden päivän jaksona, fibromyalgia- ja diabeteskurssit kahtena viiden päivän jaksona, joiden väli oli noin 6 kuukautta. Sovittuna ajanjaksona vuosien 2014-15 aikana kursseille osallistui neljässä kuntoutuslaitoksessa yhteensä 581 kuntoutujaa. Heistä 377 (65 \%) antoi tietoon perustuvan kirjallisen suostumuksen osallistua tutkimukseen. Kaikki suostumuksensa antaneet vastasivat alkukyselylomakkeeseen.

Syöpäkurssille osallistuneita oli tutkimuksessa 198, fibromyalgiakurssille 100 ja diabeteskurssille 79 henkilöä. Naisten osuus oli suurin fibromyalgiakursseilla (91 \%) ja pienin diabeteskursseilla (67\%). Osallistujien keskiikä oli 56 vuotta (vaihteluväli 20-89 vuotta), syöpäkurssilla muita ryhmiä korkeampi.

Tutkimuksessa käytettiin seuraavia muuttujia:

Vastaajilta tiedusteltiin koulutusta muuttujalla, joka sisälsi sekä perus- että ammattikoulutusta koskevaa tietoa. Tätä tutkimusta varten muuttuja jaettiin kahteen luokkaan: 1 = perus- tai keskikoulu tai ammatillinen keskiasteen tutkinto, 2 = ylioppilastutkinto, opisto-, ammattikorkeakoulu- tai korkeakoulututkinto.

Elämäntilanteen mukaan vastaajat luokiteltiin neljään ryhmään: 1 = koko- tai osapäivätyössä tai koulutuksessa, 2 = työttömänä, lomautettuna, sairauslomalla tai kuntoutuksessa, 3 = työkyvyttömyyseläkkeellä tai kuntoutustuella, 4 = muulla eläkkeellä.

Terveydentilaa arvioitiin 5-portaisella asteikolla 1 = hyvä, ..., 5 = huono.

Fyysisten ja psyykkisten rajoitusten vaikeusastetta kuvattiin kaksiosioisella kysymyksellä, jossa vastaaja arvioi sairauden, vamman tai muun syyn aiheuttamia fyysisten tai psyykkisten toimintojen rajoituksia a) omassa kodissa ja b) kodin ulkopuolella toimiessaan 4-portaisella asteikolla $(1=\mathrm{ei}, \ldots, 4=$ paljon). Summamuuttujan vaihteluväli on 2-8, jossa korkeampi arvo merkitsee vaikeampia rajoituksia.

Masennusoireilua selvitettiin CIDI-SF -haastattelun kahdella kysymyksellä (Kessler 
ym. 1998), joista vähintään toiseen annettu myöntävä vastaus tarkoittaa todennäköistä masennusta.

Sairauskäsityksiä selvitettiin Illness perception questionnaire (IPQ) -kyselyn (Weinman ym. 1996) lyhennetyllä versiolla (BIPQ; Broadbent ym. 2006); siinä käsityksiä sairaudesta arvioidaan kahdeksalla osa-alueella asteikolla 0-10 (taulukko 2).

Hallinnan tunnetta selvitettiin Pearlinin ja Schoolerin (1978) Sense of Mastery -kyselyllä, joka koostuu 7 väittämästä (mm. "Kykenen tekemään lähes kaiken sen minkä todella päätän tehdä” ja "Tunnen usein avuttomuutta elämän ongelmien edessä"). Arviointi tehdään neliportaisella asteikolla ( 1 = täysin samaa mieltä, ..., 4 = täysin eri mieltä), ja muodostettavan summamuuttujan vaihteluväli on 7-28, jossa korkeampi pistemäärä merkitsee vahvempaa hallintaa. Mittarin reliabiliteetti (Cronbachin alfa) oli aineistossa 0,79.

Terveyteen liittyvää valtaistumista selvitettiin 11 osiolla, joita valittaessa käytettiin apuna aikaisempia tutkimuksia (Koren ym. 1992, Walker ym. 2010). Osiot olivat väittämiä, joiden paikkansa pitävyyttä arvioitiin 5-portaisella asteikolla ( $1=$ ei pidä lainkaan paikkaansa, ... , 5 = pitää täysin paikkansa). Summamuuttujan reliabiliteetti (alfa) oli 0,79. Faktorianalyysin (pääkomponenttianalyysi, Varimax-rotaatio) perusteella muodostettiin kolme osa-asteikkoa: 1) Sairauden ja palvelujen tiedollinen hallinta (4 osiota; esim. "Olen oppinut ymmärtämään millaisista palveluista minulle on eniten hyötyä"; "Tunnen hyvin sairauteni tai toimintarajoitteeni ja tiedän, mitkä tekijät siihen vaikuttavat”; alfa=0.78); 2) Psykososiaalinen hallinta ja valmius kokemusten jakamiseen (5 osiota; esim. "Pystyn käsittelemään varsin hyvin sairauteeni tai toimintarajoitteeseeni liittyviä ongelmia"; "Voin käyttää kokemuksiani auttaakseni muita ihmisiä, joilla on samanlaisia ongelmia"; alfa=0.69); 3) Tasa-arvoinen suhde asiantuntijoihin (2 osiota; esim. "Jos jokin kuntoutuspalvelu ei kohdallani toimi, kerron aina siitä ja ehdotan jotain muuta"; Spearman-Brown -reliabiliteet$\mathrm{ti}=0.64)$. Asteikon ja osa-asteikkojen summat jaettiin osioiden määrällä, jolloin kunkin as- teikon vaihteluväli on 1-5.

Sosiaalisella luottamuksella tarkoitetaan ihmisen käsitystä siitä, missä määrin hän kokee voivansa luottaa ympärillään oleviin ihmisiin, ja institutionaalisella luottamuksella ihmisen käsitystä siitä, missä määrin hän kokee voivansa luottaa yhteiskunnan instituutioihin, viranomaisiin tai palvelujärjestelmään yleensä (ks. Mohseni ym. 2007, Grönlund \&t Setälä 2012, Härkäpää ym. 2014). Sosiaalisen luottamuksen mittari (alfa=0.77) muodostettiin kolmesta osiosta (esim. "Minulla on liian vähän ihmisiä, joihin voin luottaa") ja institutionaalisen luottamuksen mittari (alfa=0.71) neljästä osiosta (esim. "Kansalaiset eivät nykyään voi luottaa viranomaisen toimintaan"; "Suomalaisessa palvelujärjestelmässä asiakkaat ovat keskenään tasa-arvoisia"), joihin otettiin kantaa 5-portaisella asteikolla (1 = täysin eri mieltä,..., 5 = täysin samaa mieltä). Summat jaettiin osioiden lukumäärällä (vaihteluväli 1-5), jossa korkeampi arvo merkitsee vahvempaa luottamusta.

Vastaajilta tiedusteltiin aikaisempaa osallistumista sopeutumisvalmennuskurssille (1 = en, 2 = kyllä); tarkennuksena tiedusteltiin, milloin viimeksi ja mille kurssille.

Sopeutumisvalmennukseen kohdistuvia odotuksia selvitettiin 24 osiolla ja 4-portaisella asteikolla ( $1=$ ei odotuksia tai tarvetta, ..., 4 = paljon odotuksia). Faktorianalyysin (pääkomponenttianalyysi, Varimax-rotaatio) perusteella odotuksen kohteista muodostettiin neljä summamuuttujaa: 1) Tieto palveluista, etuuksista ja tuen lähteistä (6 osiota, esim. "tietoa Kelan etuuksista"; "tietoa kunnan tarjoamista tukimuodoista"; "tietoa lähimmästä hoito- ja viranomaistahosta, jolta saa apua tarvittaessa"; "tietoa potilas- tai muiden järjestöjen toiminnasta"; alfa $=0.88$ ); 2) Psykososiaalinen tuki voimavarojen vahvistumiseen ja selviytymiseen (5 osiota, esim. "tukea omien voimavarojen tunnistamiseen ja vahvistamiseen"; "tukea tunnetilojen käsittelyyn"; "tukea sairauden tai elämäntilanteen hyväksymiseen"; alfa=0.83); 3) Tieto sairaudesta ja sen hoidosta (3 osiota; esim. "tietoa omasta sairaudesta ja toimintakykyyn vaikuttavista tekijöistä"; "tietoa hoidosta ja kuntou- 
tuksesta"; alfa=0.84); 4) Vertaistuki ja kuulluksi tuleminen (4 osiota, esim. "vertaistukea toisilta kurssilaisilta, joilla on samankaltainen sairaus tai elämäntilanne"; "kuulluksi tulemista, keskustelua ja kokemusten jakamista"; al$\mathrm{fa}=0.77)$. Kullakin faktorilla osioiden summat jaettiin osioiden lukumäärällä, jolloin vaihteluväli on 1-4.

\section{Tilastolliset analyysit}

Tilastolliset analyysit tehtiin SPSS Statistics -ohjelman versiolla 21 . Ne perustuivat ristiintaulukointien lisäksi yksisuuntaiseen varianssianalyysiin, Kruskal-Wallisin nonparametriseen varianssianalyysiin sekä logistiseen regressioanalyysiin.

Logistisissa regressioanalyyseissa käytettiin aluksi selitettävinä muuttujina hallinnan tunnetta ja terveyteen liittyvää valtaistumista. Selitettävät muuttujat dikotomisoitiin niin, että analyyseissa ennustettiin vahvempaa hallinnan tunnetta (> 19) ja terveyteen liittyvää valtaistumista (> 3.7). Selittävinä muuttujina olivat koulutus, elämäntilanne, sosiaalinen ja institutionaalinen luottamus, masennusoire sekä fyysisten ja psyykkisten rajoitusten aste. Analyyseissa selvitettiin kunkin selittävän muuttujan yhteys selitettävään muuttujaan erikseen käyttäen kovariantteina ikää ja sukupuolta. Sosiaalista ja institutionaalista luottamusta kuvaavat muuttujat dikotomisoitiin analyyseja varten.

Sen jälkeen selitettävinä muuttujina käytettiin sopeutumisvalmennukseen kohdistuneita odotuksia. Analyyseja varten odotusfaktorit dikotomisoitiin niin, että analyyseissa ennustettiin vahvempia odotuksia (faktori 1: > 2.5; faktori 2: > 3; faktorit 3 ja 4 : > 3.4). Selittäviä muuttujia olivat sairauskäsitykset, hallinnan tunne ja terveyteen liittyvän valtaistumisen kolme faktoria. Analyyseissa selvitettiin kunkin selittävän muuttujan yhteys kuhunkin selitettävään muuttujaan erikseen käyttäen kovariantteina ikää, sukupuolta ja kurssiryhmää. Analyyseja varten sairauskäsitysmuuttujat ja valtaistumisen osa-asteikot dikotomisoitiin.

\section{Tulokset}

Kurssiryhmät erosivat paitsi ikänsä ja sukupuolensa myös elämäntilanteensa suhteen: syöpäkurssille osallistuneista vajaa kolmannes oli työssä ja lähes puolet ikään perustuvalla eläkkeellä, kun taas fibromyalgiakursseilla olleista yli puolet ja diabeteskurssilaisista 72 \% oli työssä (taulukko 1). Kurssiryhmät eivät eronneet tilastollisesti merkitsevästi koulutuksen suhteen. Ylioppilastutkinnon tai opistotai korkeakoulututkinnon suorittaneita oli 51 \%, lyhemmän koulutuksen saaneita $49 \%$.

Kolmannes osallistujista arvioi terveydentilansa hyväksi tai melko hyväksi. Ryhmät erosivat toisistaan tilastollisesti merkitsevästi sekä koetun terveydentilan, toimintarajoitusten että masennusoireiden suhteen. Fibromyalgiakursseille osallistuneet raportoivat terveyteen liittyviä ongelmia muita ryhmiä enemmän. Osa vastanneista oli osallistunut sopeutumisvalmennuskurssille myös aikaisemmin, diabeteskurssilaiset muita ryhmiä useammin. (Taulukko 1.) Aikaisemmat kurssit oli järjestetty Kelan, terveydenhuollon tai Raha-automaattiyhdistyksen tuella tai järjestöjen toimintana.

Ryhmät erosivat sairauskäsitystensä osalta toisistaan. Fibromyalgiaa sairastavat arvioivat sairauden aiheuttavan oireita ja vaikuttavan elämään enemmän kuin muut ryhmät. He olivat huolestuneempia sairaudestaan ja kokivat ymmärtävänsä sitä huonommin kuin muut ryhmät. Diabetesryhmä arvioi sekä mahdollisuutensa vaikuttaa sairauteen että hoidon vaikutukset muita ryhmiä myönteisemmin. Syöpää sairastavat kokivat mahdollisuutensa vaikuttaa sairauteensa vähäiseksi. (Taulukko 2.) Vastaajien sairauskäsityksissä oli paljon hajontaa myös kunkin ryhmän sisällä.

Ryhmät eivät eronneet toisistaan tilastollisesti merkitsevästi hallinnan tunteessa. Sen sijaan terveyteen liittyvä valtaistuminen sekä sosiaalinen ja institutionaalinen luottamus olivat fibromyalgiaryhmässä heikommat kuin muissa ryhmissä. (Taulukko 3.)

Eniten odotuksia kohdistui sairautta ja sen hoitoa ja kuntoutusta koskevaan tietoon ja tukeen sekä vertaistukeen ja kuulluksi tulemiseen. Psykososiaalista tukea ja opastusta 
Taulukko 1. Taustatietoja kurssiryhmittäin ja ryhmien välisten erojen tilastolliset merkitsevyydet.

\begin{tabular}{|c|c|c|c|c|c|}
\hline & \multicolumn{3}{|c|}{ Kurssiryhmä } & \multirow[b]{2}{*}{$\begin{array}{c}\text { Kaikki } \\
(n=377)\end{array}$} & \multirow[b]{2}{*}{$p$} \\
\hline & $\begin{array}{c}\text { Syöpä } \\
(n=198)\end{array}$ & $\begin{array}{l}\text { Fibromyalgia } \\
\qquad(n=100)\end{array}$ & $\begin{array}{l}\text { Diabetes } \\
(n=79)\end{array}$ & & \\
\hline $\begin{array}{l}\text { Sukupuoli, naisia \% } \\
\text { Ikä, M (sd) }\end{array}$ & $\begin{array}{c}73.6 \\
63.0(9.7)\end{array}$ & $\begin{array}{c}91.0 \\
48.5(11.0)\end{array}$ & $\begin{array}{c}66.7 \\
46.1(11.6)\end{array}$ & $\begin{array}{c}76.8 \\
55.6(13.1)\end{array}$ & $\begin{array}{l}.000 \\
.000\end{array}$ \\
\hline $\begin{array}{l}\text { Koulutus, \% } \\
\text {-ylioppilas-, opisto- } \\
\text { tai korkeakoulututkinto }\end{array}$ & 48.2 & 48.0 & 61.5 & 50.9 & NS \\
\hline \multicolumn{6}{|l|}{ Elämäntilanne, \% } \\
\hline - työssä & 29.1 & 55.6 & 71.8 & 45.0 & .000 \\
\hline $\begin{array}{l}\text { - sairauspäiväraha, } \\
\text { kuntoutus, työtön }\end{array}$ & 9.7 & 24.2 & 14.1 & 14.5 & \\
\hline $\begin{array}{l}\text { - työkyvyttömyyseläke, } \\
\text { kuntoutustuki }\end{array}$ & 12.8 & 15.2 & 9.0 & 12.6 & \\
\hline \multirow[t]{2}{*}{ - muu eläke } & 48.5 & 5.1 & 5.1 & 27.9 & \\
\hline & 100. & 100. & 100. & 100. & \\
\hline \multicolumn{6}{|l|}{ Koettu terveydentila, \% } \\
\hline - hyvä/melko hyvä & 35.7 & 13.1 & 52.6 & 33.2 & .000 \\
\hline - keskitasoinen & 51.0 & 42.4 & 30.3 & 44.5 & \\
\hline \multirow[t]{2}{*}{ - huono/melko huono } & 13.3 & 44.4 & 17.1 & 22.4 & \\
\hline & 100. & 100. & 100. & 100. & \\
\hline $\begin{array}{l}\text { Fyysiset ja psyykkiset } \\
\text { rajoitukset, M (sd) }\end{array}$ & $\begin{array}{c}3.82 \\
(1.38)\end{array}$ & $\begin{array}{l}4.73) \\
(1.17\end{array}$ & $\begin{array}{c}3.31 \\
(1.35)\end{array}$ & $\begin{array}{c}3.95 \\
(1.41)\end{array}$ & .000 \\
\hline Masennusoire, \% & 45.1 & 63.5 & 51.9 & 51.4 & .013 \\
\hline $\begin{array}{l}\text { Aiempi } \\
\text { sopeutumisvalmennus, \% }\end{array}$ & 23.5 & 21.9 & 44.7 & 27.4 & .001 \\
\hline
\end{tabular}

Taulukko 2. Sairauskäsitykset (BIPQ) kurssiryhmittäin ja kaikilla vastanneilla, M (sd).

\begin{tabular}{|c|c|c|c|c|c|}
\hline BIPQ-osio & Syöpä & Fibromyalgia & Diabetes & Kaikki & $\mathrm{p}^{1}$ \\
\hline $\begin{array}{l}\text { Kuinka paljon sairaus vaikuttaa } \\
\text { elämään ( } 0=\text { ei lainkaan, } \\
10=\text { erittäin paljon) }\end{array}$ & $\begin{array}{c}5.84 \\
(2.63)\end{array}$ & $\begin{array}{c}7.60 \\
(1.46)\end{array}$ & $\begin{array}{c}6.67 \\
(2.38)\end{array}$ & $\begin{array}{c}6.48 \\
(2.43)\end{array}$ & .000 \\
\hline $\begin{array}{l}\text { Kuinka kauan olettaa sen } \\
\text { jatkuvan ( } 0 \text { = vain lyhyen aikaa, } \\
10=\text { aina, pysyvästi) }\end{array}$ & $\begin{array}{c}7.97 \\
(2.60)\end{array}$ & $\begin{array}{c}7.19 \\
(1.36)\end{array}$ & $\begin{array}{c}8, .74 \\
(2.18)\end{array}$ & $\begin{array}{c}8.94 \\
(2.38)\end{array}$ & .000 \\
\hline $\begin{array}{l}\text { Kuinka paljon pystyy itse } \\
\text { vaikuttamaan siihen } \\
(0=\text { en mitenkään, } \\
10=\text { erittäin paljon) }\end{array}$ & $\begin{array}{c}4.86 \\
(2.80)\end{array}$ & $\begin{array}{l}6.03 \\
2.36)\end{array}$ & $\begin{array}{c}6.82 \\
(2.57)\end{array}$ & $\begin{array}{c}5.59 \\
(2.76)\end{array}$ & .000 \\
\hline $\begin{array}{l}\text { Kuinka paljon arvelee hoidon } \\
\text { vaikuttavan siihen } \\
\text { ( } 0=\text { ei ollenkaan, } 10=\text { erittäin paljon) }\end{array}$ & $\begin{array}{c}7.09 \\
(1.95)\end{array}$ & $\begin{array}{c}7.01 \\
(1.96)\end{array}$ & $\begin{array}{c}7.81 \\
(1.49)\end{array}$ & $\begin{array}{c}7.22 \\
(1.89)\end{array}$ & .009 \\
\hline $\begin{array}{l}\text { Kuinka paljon se aiheuttaa } \\
\text { oireita ( } 0=\text { ei mitään oireita, } \\
10=\text { paljon vaikeita oireita) }\end{array}$ & $\begin{array}{c}5.26 \\
(2.62)\end{array}$ & $\begin{array}{c}7.98 \\
(1.33)\end{array}$ & $\begin{array}{c}6.18 \\
(1.98)\end{array}$ & $\begin{array}{c}6.17 \\
2.49)\end{array}$ & .000 \\
\hline $\begin{array}{l}\text { Kuinka huolestunut on siitä } \\
\text { (0 = en lainkaan, } \\
10=\text { erittäin huolestunut) }\end{array}$ & $\begin{array}{c}6.21 \\
(2.74)\end{array}$ & $\begin{array}{c}7.18 \\
(2.19)\end{array}$ & $\begin{array}{c}6.78 \\
(2.41)\end{array}$ & $\begin{array}{c}6.58 \\
(2.56)\end{array}$ & .018 \\
\hline $\begin{array}{l}\text { Kuinka hyvin kokee ymmärtävänsä } \\
\text { sitä ( } 0 \text { = en lainkaan, } \\
10 \text { = erittäin hyvin) }\end{array}$ & $\begin{array}{c}7.29 \\
(2.22)\end{array}$ & $\begin{array}{c}6.13 \\
(2.57)\end{array}$ & $\begin{array}{c}7.23 \\
(1.84)\end{array}$ & $\begin{array}{c}6.97 \\
(2.30)\end{array}$ & .000 \\
\hline $\begin{array}{l}\text { Kuinka paljon se herättää } \\
\text { tunteita ja tunnereaktioita } \\
\text { (vihaa, pelkoa, masennusta) } \\
\text { ( } 0 \text { = ei vaikuta lainkaan, } \\
10 \text { = erittäin voimakkaasti) }\end{array}$ & $\begin{array}{c}6.35 \\
(2.66)\end{array}$ & $\begin{array}{c}7.09 \\
(2.34)\end{array}$ & $\begin{array}{c}6.32 \\
(2.56)\end{array}$ & $\begin{array}{c}6.54 \\
(2.58)\end{array}$ & .049 \\
\hline
\end{tabular}

${ }^{1}$ Kurssiryhmien erot testattu Kruskal-Wallisin nonparametrisella varianssianalyysilla. 
Taulukko 3. Hallinnan tunne, terveyteen liittyvä valtaistuminen, institutionaalinen ja sosiaalinen luottamus sekä kurssia koskevat odotukset kurssiryhmittäin ja kaikilla vastanneilla, M (sd).

\begin{tabular}{|c|c|c|c|c|c|}
\hline & \multicolumn{3}{|c|}{ Kurssiryhmä } & \multirow[b]{2}{*}{ Kaikki } & \multirow[b]{2}{*}{$\mathrm{p}^{*}$} \\
\hline & Syöpä & Fibromyalgia & Diabetes & & \\
\hline Hallinnan tunne & $19.02(3.89)$ & $18.89(4.62)$ & $20.22(4.45)$ & $19.25(4.23)$ & .068 \\
\hline $\begin{array}{l}\text { Terveyteen liittyvä } \\
\text { valtaistuminen }\end{array}$ & $3.79(0.52)^{a}$ & $3.39(0.57)^{\mathrm{ab}}$ & $3.69(0.52)^{b}$ & $3.66(0.58)$ & .000 \\
\hline $\begin{array}{l}\text {-F1: Sairauden ja palvelujen } \\
\text { tiedollinen hallinta }\end{array}$ & $3.47(0.67)$ & $2.85(0.88)$ & $3.45(0.69)$ & $3.30(0.78)$ & $.000^{1}$ \\
\hline $\begin{array}{l}\text {-F2: Psykososiaalinen hallinta, } \\
\text { valmius kokemusten jakamiseen }\end{array}$ & $3.98(0.63)^{\mathrm{ac}}$ & $3.54(0.62)^{a}$ & $3.75(0.66)^{c}$ & $3.81(0.66)$ & .000 \\
\hline $\begin{array}{l}\text {-F3: Tasa-arvoinen suhde } \\
\text { asiantuntijoihin }\end{array}$ & $3.92(0.78)$ & $4.09(0.72)$ & $3.97(0.69)$ & $3.97(0.75)$ & .172 \\
\hline Institutionaalinen luottamus & $3.45(0.68)$ & $3.11(0.85)$ & $3.29(0.65)$ & $3.32(0.74)$ & $.002^{1}$ \\
\hline Sosiaalinen luottamus & $3.68(0.83)^{a}$ & $3.28(1.02) a$ & $3.57(0.98)$ & $3.55(0.93)$ & .002 \\
\hline \multicolumn{6}{|l|}{ Odotusfaktorit } \\
\hline $\begin{array}{l}\text {-Tieto palveluista ja } \\
\text { tukitahoista }\end{array}$ & $2.38(0.77)^{\mathrm{a}, \mathrm{c}}$ & $2.62(0.79)^{a, b}$ & $2.02(0.79)^{\mathrm{b}, \mathrm{c}}$ & $2.37(0.81)$ & .000 \\
\hline -Psykosos. tuki selviytymiseen & $2.87(0.65)^{c}$ & $3.00(0.70)^{b}$ & $2.62(0.79)^{\mathrm{b}, \mathrm{c}}$ & $2.85(0.70)$ & .002 \\
\hline $\begin{array}{l}\text {-Tieto sairaudesta ja sen } \\
\text { hoidosta }\end{array}$ & $3.11(0.62)^{a}$ & $3.63(0.51)^{a, b}$ & $3.21(0.66)^{b}$ & $3.27(0.64)$ & .000 \\
\hline $\begin{array}{l}\text {-Vertaistuki ja } \\
\text { kuulluksi tuleminen }\end{array}$ & $3.17(0.63)$ & $3.28(0.64)^{b}$ & $2.98(0.64)^{b}$ & $3.16(0.64)$ & .009 \\
\hline
\end{tabular}

"Ryhmien väliset erot testattu yksisuuntaisella varianssianalyysilla tai Kruskal-Wallisin nonparametrisella varianssianalyysilla(').

Parittaiset vertailut on tehty riippuvien ryhmien t-testillä ( $a: p<.05$ syöpä- vs. fibromyalgiaryhmä; $b: p<.05$ fibromyalgia- vs. diabetesryhmä; c: $p<.05$ syöpä- vs. diabetesryhmä).

sairauden ja elämäntilanteen hyväksymiseen, voimavarojen vahvistamiseen ja tunnetilojen käsittelyyn kaivattiin diabetesryhmässä muita ryhmiä vähemmän. Tietoja palveluista, etuuksista ja tuen lähteistä odotettiin fibromyalgiaryhmässä eniten ja diabetesryhmässä vähiten. (Taulukko 3.)

Taulukon 4 logistisissa regressioanalyyseissa selitettävinä muuttujina ovat hallinnan tunne ja terveyteen liittyvä valtaistuminen. Kovarianteista iällä oli positiivinen yhteys $(\mathrm{p}<.05)$ terveyteen liittyvään valtaistumiseen mutta ei hallinnan tunteeseen. Verrattuna työssä oloon sairauslomalla tai työttömänä sekä työkyvyttömyyseläkkeellä oleminen alensivat hallinnan tunteen todennäköisyyttä. Vahvempi sosiaalinen ja institutionaalinen luottamus lisäsivät sekä hallinnan tunteen että terveyteen liittyvän valtaistumisen todennäköisyyttä; masennusoireet sekä fyysiset ja psyykkiset rajoitukset vähensivät sitä. Koulutuksella ei ollut yhteyttä kumpaankaan seli- tettävään muuttujaan. (Taulukko 4.)

Taulukossa 5 on esitetty sairauskäsitysten, hallinnan tunteen ja terveyteen liittyvän valtaistumisen yhteydet odotusfaktoreihin. Kovarianteista sukupuoli oli yhteydessä vertaistukea koskeviin odotuksiin: miehillä niitä oli vähemmän kuin naisilla.

Palvelu- yms. tietoja koskevien odotusten todennäköisyyttä lisäsivät sairauskäsitysmuuttujista oireiden määrä ja käsitys hoidon paremmista vaikutuksista. Psykososiaalista tukea koskevien odotusten todennäköisyyttä lisäsivät oireiden suurempi määrä, huolestuneisuus ja kielteiset tunnereaktiot sekä käsitys hoidon paremmista vaikutuksista. Vahvempi hallinnan tunne ja valtaistumisfaktoreista parempi tiedollinen hallinta alensivat psykososiaaliseen tukeen kohdistuvien odotusten todennäköisyyttä. Sairautta ja sen hoitoa koskevaan tietoon kohdistuvien odotusten todennäköisyyttä lisäsivät sairauskäsitysmuuttujista oireiden, huolestuneisuuden ja tunnereak- 
Taulukko 4. Elämäntilanteen, sosiaalisen ja institutionaalisen luottamuksen, masennusoireiden sekä fyysisten ja psyykkisten rajoitusten yhteydet hallinnan tunteeseen ja terveyteen liittyvään valtaistumiseen.

\begin{tabular}{|l|c|c|}
\hline & Hallinnan tunne & $\begin{array}{c}\text { Terveyteen liittyvä } \\
\text { valtaistuminen }\end{array}$ \\
\hline & OR $(95 \% \mathrm{Cl})$ & OR $(95 \% \mathrm{Cl})$ \\
\hline Elämäntilanne & & \\
\hline $\begin{array}{l}\text { Työttömyys, sairausloma jne. } \\
\text { vs. työ tai koulutus }\end{array}$ & $0.22(0.10-0.46)^{* * *}$ & \\
\hline $\begin{array}{l}\text { Työkyvyttömyyseläke } \\
\text { vs. työ tai koulutus }\end{array}$ & $0.28(0.13-0.60)^{* * *}$ & \\
\hline $\begin{array}{l}\text { Muu eläke } \\
\text { vs. työ tai koulutus }\end{array}$ & $0.94(0.47-1.88)$ & $2.61(1.69-4.01)^{* * *}$ \\
\hline $\begin{array}{l}\text { Sosiaalinen luottamus } \\
\text { ( } \geq 3.5 \text { vs. alempi arvo) }\end{array}$ & $3.27(2.10-5.12)^{* * *}$ & $1.69(1.11-2.57)^{*}$ \\
\hline $\begin{array}{l}\text { Institutionaalinen luottamus } \\
\text { ( } \geq 3.5 \text { vs. alempi arvo) }\end{array}$ & $2.12(1.38-3.25)^{* * *}$ & $0.36(0.24-0.56)^{* * *}$ \\
\hline Masennusoire (kyllä vs. ei) & $0.19(0.12-0.30)^{* * *}$ & $0.72(0.61-0.84)^{* * *}$ \\
\hline $\begin{array}{l}\text { Fyysiset ja psyykkiset } \\
\text { rajoitukset }\end{array}$ & $0.62(0.52-0.73)^{* * *}$ & \\
\hline
\end{tabular}

Muuttujien yhteyttä tarkasteltiin logistisella regressioanalyysilla, jossa selittäjinä olivat kerrallaan yksi muuttuja sekä ikä ja sukupuoli kovariantteina. Taulukossa on esitetty vain tilastollisesti merkitsevät yhteydet $(* * * p<.001$, **p<.01, *p<.05). OR = ristitulosuhde, $95 \% \mathrm{Cl}=95 \%$ :n luottamusväli.

Taulukko 5. Sairauskäsitysten, hallinnan tunteen ja terveyteen liittyvän valtaistumisen yhteydet vahvempiin kurssia koskeviin odotuksiin neljällä odotusfaktorilla.

\begin{tabular}{|c|c|c|c|c|}
\hline & \multicolumn{4}{|c|}{ Kurssia koskevat odotukset } \\
\hline & $\begin{array}{l}\text { Tieto } \\
\text { palveluista ja } \\
\text { tukitoimista }\end{array}$ & $\begin{array}{c}\text { Psykoso- } \\
\text { siaalinen tuki } \\
\text { selviytymiseen }\end{array}$ & $\begin{array}{c}\text { Tieto } \\
\text { sairaudesta ja } \\
\text { sen hoidosta }\end{array}$ & $\begin{array}{l}\text { Vertaistuki ja } \\
\text { kuulluksi } \\
\text { tuleminen }\end{array}$ \\
\hline & OR $(95 \% \mathrm{Cl})$ & OR $(95 \% \mathrm{Cl})$ & OR $(95 \% \mathrm{Cl})$ & OR $(95 \% \mathrm{Cl})$ \\
\hline \multicolumn{5}{|l|}{ Sairauskäsitysosiot (BIPQ) } \\
\hline $\begin{array}{l}\text { Sairauden vaikutukset } \\
\text { ( } \geq 8 \text { vs. alempi arvo) }\end{array}$ & & & & $\begin{array}{l}1.70^{*} \\
(1.08-2.67)\end{array}$ \\
\hline $\begin{array}{l}\text { Omat vaikutusmahdollisuudet } \\
\text { ( } \geq 7 \text { vs. alempi arvo) }\end{array}$ & & & $\begin{array}{l}1.91^{* *} \\
(1.19-3.07)\end{array}$ & $\begin{array}{l}1.77^{*} \\
(1.12-2.79)\end{array}$ \\
\hline $\begin{array}{l}\text { Hoidon vaikutukset } \\
\text { ( } \geq 8 \text { vs. alempi arvo) }\end{array}$ & $\begin{array}{l}1.88^{* *} \\
(1.18-2.99)\end{array}$ & $\begin{array}{l}2.30 * * * \\
(1.46-3.64)\end{array}$ & $\begin{array}{l}3.34 * * * \\
(2.04-5.48)\end{array}$ & $\begin{array}{l}2.43 * * * \\
(1.56-3.81)\end{array}$ \\
\hline $\begin{array}{l}\text { Oireet } \\
\text { ( } \geq 8 \text { vs. alempi arvo) }\end{array}$ & $\begin{array}{l}2.21^{* *} \\
(1.33-3.66)\end{array}$ & $\begin{array}{l}2.09 * * \\
(1.27-3.44)\end{array}$ & $\begin{array}{l}1.79 * \\
(1.09-2.93)\end{array}$ & \\
\hline $\begin{array}{l}\text { Huolestuneisuus } \\
\text { ( } \geq 8 \text { vs. alempi arvo) }\end{array}$ & & $\begin{array}{l}2.16 * * * \\
(1.38-3.38)\end{array}$ & $\begin{array}{l}2.09 * * \\
(1.32-3.29)\end{array}$ & $\begin{array}{l}1.73^{*} \\
(1.12-2.68)\end{array}$ \\
\hline $\begin{array}{l}\text { Tunnereaktiot } \\
\text { ( } \geq 8 \text { vs. alempi arvo) }\end{array}$ & & $\begin{array}{l}2.85 * * * \\
(1.81-4.49)\end{array}$ & $\begin{array}{l}1.92 * * \\
(1.22-3.03)\end{array}$ & $\begin{array}{l}1.49 \\
(0.97-2.30)\end{array}$ \\
\hline Hallinnan tunne & & $\begin{array}{l}0.95^{*} \\
(0.90-1.00) \\
\end{array}$ & & \\
\hline \multicolumn{5}{|l|}{$\begin{array}{l}\text { Terveyteen liittyvä } \\
\text { valtaistuminen }\end{array}$} \\
\hline $\begin{array}{l}\text { F1: Sairauden ja palvelujen } \\
\text { tiedollinen hallinta } \\
\text { ( } \geq 3.5 \text { vs. alempi arvo) }\end{array}$ & & $\begin{array}{l}0.63^{*} \\
(0.40-0.99)\end{array}$ & $\begin{array}{l}0.60^{*} \\
(0.38-0.96)\end{array}$ & $\begin{array}{l}1.88^{* *} \\
(1.19-2.97)\end{array}$ \\
\hline $\begin{array}{l}\text { F2: Psykososiaalinen hallinta, } \\
\text { valmius kokemusten jakamiseen } \\
\text { ( } \geq 4.0 \text { vs. alempi arvo) }\end{array}$ & & & $\begin{array}{l}1.82^{*} \\
(1.12-2.98)\end{array}$ & $\begin{array}{l}2.33 * * * \\
(1.47-3.70)\end{array}$ \\
\hline
\end{tabular}

Muuttujien yhteyksiä tarkasteltiin logistisella regressioanalyysilla, joissa selittäjinä olivat kerrallaan yksi selittävä muuttuja sekä ikä, sukupuoli ja kurssiryhmä kovariantteina. Taulukossa on esitetty vain tilastollisesti merkitsevät yhteydet $(* * * p<.001, * * \mathrm{p}<.01, * \mathrm{p}<.05)$. OR = ristitulosuhde, $95 \% \mathrm{Cl}=95 \%:$ n luottamusväli. 
tioiden suurempi määrä ja toisaalta käsitys siitä, että hoidolla ja omalla toiminnalla on mahdollisuus vaikuttaa sairauteen. Valtaistumisfaktoreista parempi tiedollinen hallinta vähensi sairaustietoon kohdistuvien odotusten todennäköisyyttä ja vahvempi psykososiaalinen hallinta lisäsi sitä. Vertaistukea ja kuulluksi tulemista koskevien odotusten todennäköisyyttä lisäsivät sairauskäsitysmuuttujista erityisesti käsitys hoidon paremmista vaikutuksista mutta myös omat vaikutusmahdollisuudet, huolestuneisuus sekä sairauden vaikutukset elämään. Valtaistumisfaktoreista sairauden hyvä tiedollinen ja psykososiaalinen hallinta lisäsivät vertaistukea koskevia odotuksia. (Taulukko 5.)

\section{Pohdinta}

Tarkastelun kohteena olivat eri kuntoutuslaitosten sopeutumisvalmennuskursseille saapuvien henkilöiden sairauskäsitykset ja hallintakokemukset sekä ne odotukset, joita heillä oli sopeutumisvalmennuksesta. Sairauskäsityksiä kartoitettiin Broadbentin ym:iden (2006) lyhyellä kyselyllä, joka Leventhalin ym:iden (1992a) itsesäätelymallin mukaisesti selvitti toisaalta tiedollis-kognitiivisia käsityksiä ja uskomuksia sairauden luonteesta ja sen merkityksestä, toisaalta sairautta koskevia emotionaalisia reaktioita, joita ovat huolestuneisuus, viha, pelko ja masennus. Edellä mainitun Leventhalin ym:iden mallin perusajatuksena on, että ihminen valitsee muodostamiensa sairauskäsitysten pohjalta itselleen sopivat selviytymiskeinot, joista sosiaalisen tai asiantuntijatuen hakeminen tai hakeutuminen kuntoutukseen ovat esimerkkejä. Hallintaa tarkasteltiin kahdella tasolla, toisaalta yleisenä hallinnan tunteena eli kokemuksena omista mahdollisuuksista vaikuttaa omaan elämään, toisaalta konkreettisemmalla tasolla terveyteen liittyvänä valtaistumisena, jonka ulottuvuuksina olivat kokemukset sairauden tiedollisesta ja psykososiaalisesta hallinnasta sekä itsensä näkeminen oman asiansa asiantuntijana ammattilaisten kanssa asioitaessa. Kuntoutuksen kannalta tärkeä kysymys on, millä tavoin erilaiset käsitykset ja kokemukset vaikuttavat asiakkaiden odotuksiin heidän saapuessaan sopeutumisvalmennukseen.

Tuloksia arvioitaessa on otettava huomioon, että syöpää, fibromyalgiaa ja tyypin 1 diabetesta sairastavien ryhmät erosivat toisistaan monessa suhteessa, myös sosiaalisen asemansa osalta. Kaikissa kurssiryhmissä oli naisenemmistö, mutta diabetesryhmässä miesten osuus oli suurin eli kolmannes. Syöpäkurssille osallistuneet olivat muita ryhmiä iäkkäämpiä, ja heistä lähes puolet oli jo ikään perustuvalla eläkkeellä. Diabetesta sairastavat arvioivat terveydentilansa paremmaksi kuin muut ryhmät, kun taas fibromyalgiaryhmä arvioi oman tilanteensa selvästi muita ryhmiä huonommaksi. Masennukseen viittaavat oireet olivat yleisiä kaikissa ryhmissä, yleisimpiä kuitenkin fibromyalgiaa sairastavilla.

Sairauskäsityksissä oli selviä eroja kurssiryhmien välillä, mutta myös ryhmien sisällä arviot vaihtelivat varsin paljon. Fibromyalgiaa sairastavilla oli paljon kielteisiä käsityksiä sairaudestaan. He kokivat sairauden oireet vaikeammiksi ja sairauden vaikutukset elämään suuremmiksi kuin muut ryhmät, ja sairaus herätti heillä myös enemmän tunnereaktioita kuin muissa ryhmissä. Fibromyalgian vaikutuksia elämänlaatuun on raportoitu myös laadullisissa tutkimuksissa. Esimerkiksi Arnold ym. (2008) raportoivat kipu- ja väsymysoireiden ja depression lisäksi ihmissuhteiden ongelmia, eristäytymistä ja erilaisten aktiviteettien vähenemistä. Diabetesryhmä puolestaan arvioi omat mahdollisuutensa vaikuttaa sairauteensa paremmiksi kuin muut kurssiryhmät ja arvioi myös hoidon vaikutuksia muita myönteisemmin. Tämän tutkimuksen tyypin 1 diabetesta sairastava diabetesryhmä arvioi omat vaikutusmahdollisuutensa, hoidon vaikutukset ja sairauden jatkumisen melko lailla samaan tapaan kuin Broadbentin ym:iden (2006) tutkimuksen tyypin 2 diabetesta sairastavat; sen sijaan sairauden vaikutukset elämään, oireiden määrä ja sairauteen liittyvät kielteiset tunnereaktiot ovat heillä selvästi suuremmat. Syöpäkursseille osallistuneet pitivät omia mahdollisuuksiaan vaikuttaa sairauteensa selvästi heikompina kuin muut ryhmät. Yllättävä tulos oli, että he ei- 
vät kuitenkaan pitäneet sairauden vaikutuksia elämäänsä kovin suurina. Tulos voi heijastella sitä, että syöpäsairauteen liittyvät kulttuuriset uhkakuvat ovat viime vuosikymmeninä vähitellen heikentyneet samalla kun todennäköisyys selviytyä sairauden kanssa ja jopa toipua siitä on kasvanut (Pukkala ym., ei vuosil.). Syöpää sairastavien sairauskäsitykset vaihtelevat kuitenkin sairauden vaiheen mukaan, ja niissä on myös suuria kulttuurisia eroja (Kaptein ym. 2013, 2015).

Sairauskäsitysten antamaa kuvaa täydentävät terveyteen liittyvää valtaistumista koskevat tulokset. Fibromyalgiaa sairastavat kokivat sairauteen liittyvän tiedollisen ja psykososiaalisen hallintansa muita ryhmiä heikommaksi. Sairautta koskevan hallinnan puute ei ole yllättävää, kun sairauden etiologiaa tunnetaan edelleen heikosti, oirekuva vaihtelee ja sopivien hoitokeinojen löytäminen on haasteellista (Hannonen 2007, Markkula ym. 2009, Perrot ym. 2012). Syöpäkursseille osallistuneet erosivat muista ryhmistä sairauden psykososiaalisen hallinnan osalta. He kokivat pystyvänsä käsittelemään sairauden mukanaan tuomia ongelmia muita ryhmiä paremmin, keskustelemaan niistä muiden kanssa ja välittämään muille sitä koskevia kokemuksiaan. Voidaan myös kysyä, näkyykö tuloksessa psyykkinen kasvu ja voimaantuminen, jota on viime vuosina tutkittu paljon elämää uhkaavien sairauksien, muun muassa syövän, yhteydessä (esim. Lelorain ym. 2010). Kurssiryhmiä verrattaessa on kuitenkin muistettava ryhmien erilaiset taustat, joilla voi olla merkitystä tulosten ja niiden tulkinnan kannalta.

Edellä on tarkasteltu sairauskäsityksiä ja terveyteen liittyvää valtaistumista. Tutkimuksessa käytetyssä hallinnan tunteen kyselyssä (Pearlin \&t Schooler 1978) näkökulma on laajempi: sen on useissa tutkimuksessa katsottu kuvastavan yleistä elämänhallintaa (esim. Tigerstedt \&t Huhtanen 2013). Sopeutumisvalmennukseen osallistuvien yleinen hallinnan tunne oli jonkin verran heikompi kuin väestötutkimuksissa yleensä asetetut viitearvot (esim. Nyqvist ym. 2013, Järvikoski ym. 2016). Tulos ei ole yllättävä, sillä useimmiten sopeutumisvalmennukseen tullaan monin ta- voin kuormittavassa elämänvaiheessa. Hallinnan tunne ei ollut tilastollisesti merkitsevässä yhteydessä ikään, sukupuoleen eikä koulutukseen, kun taas väestöaineistoissa on todettu hallinnan tunteen heikkenevän ikääntymisen myötä ja hyvän koulutuksen vahvistavan sitä (Dalgard ym. 2007). Sen sijaan nykyhetken elämäntilanteella oli selvä yhteys hallinnan tunteeseen sopeutumisvalmennukseen tulevilla. Parhaillaan sairauslomalla, työttömänä tai ammatillisessa kuntoutuksessa olleilla sekä työkyvyttömyyseläkeläisillä elämänhallinta oli selvästi heikompi kuin työssä olleilla (vrt. Järvikoski ym. 2016). Sen sijaan ikään perustuvalla eläkkeellä olevilla elämänhallinta oli samaa tasoa työssä olevien kanssa. Pääasiallinen toiminta erottaa ihmiset toisistaan elämäntilanteen vakauden ja aineellis-sosiaalisen turvallisuuden suhteen, mikä heijastuu hallinnan kokemukseen. Elämänhallinnan perusta on yleisissä sosiaalisissa ja rakenteellisissa tekijöissä (Aneshensel 2015).

Elämäntilanteella ei kuitenkaan ollut yhteyttä terveysspesifiin valtaistumisen kokemukseen, mikä viittaa yleisen elämänhallinnan ja terveysspesifın valtaistumisen erilaiseen perustaan. Samoin on syytä panna merkille, että kurssiryhmät eivät eronneet olennaisesti toisistaan yleisessä hallinnan tunteessa toisin kuin terveyteen liittyvässä valtaistumisessa. Toiminnanrajoitukset ja masennusoireet merkitsivät tässä kuitenkin sekä alentunutta hallinnan tunnetta (vrt. Gadalla 2009) että vähäisempää terveyteen liittyvää valtaistumista. Myös sosiaalinen ja institutionaalinen luottamus olivat yhteydessä sekä vahvempaan hallinnantunteeseen että valtaistumiseen: luottamus kanssaihmisiin ja instituutioiden tukeen antaa erilaisille hallinnan kokemuksille hyvän perustan. Sosiaalisen luottamuksen ja perheeltä tai ystäviltä saadun sosiaalisen tuen yhteys hallinnan kokemukseen on todettu myös keski-ikäisiä tai iäkkäitä koskevissa väestötutkimuksissa (Nyqvist ym. 2013, Gadalla 2009, Ward 2013).

Sopeutumisvalmennukseen tulleiden odotuksia koskevista faktoreista kahdessa kysymys oli ensi sijassa tiedosta: toisessa sairautta ja sen hoitoa, toisessa palveluja, tukitaho- 
ja ja etuuksia koskevasta tiedosta. Omaa sairautta ja sen hoitoa koskevaa tietoa toivottiin kaikissa ryhmissä runsaasti huolimatta siitä, että monet olivat jo aiemmin olleet ensitieto- tai sopeutumisvalmennuskurssilla. Tiedon tarpeeseen olivat yhteydessä toisaalta sairauden oireet ja niihin liittyvä huolestuneisuus, toisaalta käsitys siitä, että sairauteen voidaan vaikuttaa omalla toiminnalla ja sopivalla hoidolla. Tietoa palveluista ja tukimuodoista kaivattiin kokonaisuutena selvästi edellistä vähemmän; faktorin yksittäisistä osioista kiinnostivat eniten Kelan etuudet ja kunnan erilaiset tukimuodot. Sekä sairautta koskevia tietoja että palvelutietoja koskevat odotukset olivat yhteydessä sairauden tiedolliseen hallintaan: ne, joilla oli pulaa tiedoista, toivoivat saavansa vastauksia kurssin aikana. Fibromyalgiaryhmässä tietoa koskevat odotukset olivat erityisen suuret, mikä selittynee osin sillä, että myös suuri osa lääkäreistä pitää sekä fibromyalgian diagnosointia että sopivien hoitokeinojen löytämistä haasteellisena (Perrot ym. 2012, Hayes ym. 2010). Fibromyalgiaa sairastavien odotukset kurssilta ovat todennäköisesti suuret myös siksi, että osalla on kokemuksia siitä, että sairauteen ei suhtauduta vakavasti (vrt. Lempp ym. 2009).

Psykososiaalisen tukeen ja vertaistukeen kohdistuvissa odotuksissa painottuvat tiedollisten kysymysten sijasta sosiaaliset ja psykososiaaliset tekijät. Ulottuvuudet eroavat kuitenkin toisistaan siten, että psykososiaalisen tuen odotuksissa näyttää painottuvan tarve saada asiantuntija-apua sairauteen liittyvien reaktioiden hallinnassa ja tunnetilojen käsittelyssä, kun taas vertaistuen ja kuulluksi tulemisen ulottuvuudella kiinnostus on muilta kurssilaisilta saatavassa tuessa, kuulluksi tulemisessa ja etäisyyden saamisessa arkielämän ongelmiin. Edellisessä painottuvat sairauteen sopeutumiseen - myös emotionaalisen tasapainon saavuttamiseen - liittyvät odotukset, kun jälkimmäisessä kyse on halusta eri osapuolia hyödyttävään sosiaaliseen vaihtoon. Odotuksia psykososiaalisen avun saamisesta on erityisesti niillä, joilla hallinnan tunne yleensä ja sairauden tiedollinen hallinta olivat heikot ja joiden emotionaaliset reaktiot sairauteen olivat voimakkaita. Vertaistukeen liittyvät odotukset ovat puolestaan suuremmat nimenomaan niillä, joilla tunne sairauden tiedollisesta ja psyykkisestä hallinnasta on vahvempi ja joilla on myös valmiutta välittää omia kokemuksiaan eteenpäin. Merkittävää on, että samansuuntainen tulos on raportoitu myös erityistä tukea tarvitsevien lasten vanhemmilla (Kippola-Pääkkönen ym. 2016).

Sopeutumisvalmennusta koskevassa keskustelussa asetetaan usein vastakkain toisaalta psyykkinen sopeutuminen sairauteen, toisaalta vammaisen ihmisen valtaistuminen. Valtaistumisen käsitettä on pidetty sopeutumisen käsitettä parempana siksi, että se korostaa hallintaa passiivisen sopeutumisen ja alistumisen sijasta (vrt. Streng ja toimituskunta 2014, Sharpe \&t Curran 2006). Toisaalta sopeutumista on tarkasteltu myös hyvää elämää tavoittelevana merkityksenhakuprosessina (Park ym. 2008, Park 2010): elämän tarkoituksen pohtimista ja tilanteen hyväksymistä pidetään tärkeänä juuri siksi, että tulevaisuuden ennustettavuuden hämäryys ja epäoikeudenmukaisuuden tunne eivät veisi tilaa ihmisen aktiiviselta elämältä. Valtaistuminen on laaja käsite, joka sisältää psyykkisen voimaantumisen lisäksi myös tiedollisen, vuorovaikutuksellisen ja toiminnallisen valtaistumisen sekä ihmisen toimintamahdollisuuksien paranemisen hänen omissa yhteisöissään.

Tutkimus käsittelee suomalaisessa kuntoutuksessa tärkeää mutta vähän tutkittua teemaa. Sen vahvuutena on vastaajien huolellinen paneutuminen kyselylomakkeen kysymyksiin. Yksittäisissä kysymyksissä puuttuvien tietojen määrä on vähäinen; lomake näytti koskettavan asioita, jotka vastaajien oli helppo kokea mielekkäinä. Tutkimuksen rajoitukset liittyvät aineiston edustavuuteen. Tutkittavat ryhmät ovat määrällisesti suurimpia Kelan sopeutumisvalmennukseen osallistuvia sairausryhmiä ja ne valittiin neuvottelujen tuloksena. Kaikki kursseille osallistuneet eivät antaneet kirjallista suostumusta osallistua tutkimukseen, eikä tutkijoilla ole tietoa siitä, miltä osin valikoituminen on tapahtunut harkinnan perusteella ja miltä osin kuntoutuslaitosten käytäntöjen takia. Kurssiryhmät eroavat toisis- 
taan useiden keskeisten ominaisuuksien osalta, mikä vaatii huomiota vertailuja tehtäessä.

Yhteenvetona voidaan todeta, että sopeutumisvalmennukseen tulevilla on monenlaisia tarpeita, jotka liittyvät sekä tiedonsaantiin, emotionaaliseen tukeen että sosiaaliseen vastavuoroisuuteen. Odotuksissa heijastuvat sekä sopeutumisen että valtaistumisen näkökulmat. Tulokset eivät viittaa passiiviseen sopeutumiseen vaan sairauden ja oman elämäntilanteen hallinnan pyrkimyksiin, joiden olennaisia osia ovat tiedollisen hallinnan ja asiantuntijatuen tarve sekä toive vertaistuen saamisesta. Osallistujien tarpeiden huomioon ottaminen valmennuksen aikana voi vaikuttaa myönteisesti myös yksilöllisiin sairauskäsityksiin. Odotukset vaihtelevat, minkä vuoksi on tärkeää ottaa huomioon myös kursseille osallistuvien asiakkaiden yksilölliset tarpeet, ei pelkästään sairausryhmän yleisiä tarpeita.

\section{Tiivistelmä}

Sopeutumisvalmennus on kuntoutusmuoto, jonka avulla pyritään tukemaan kuntoutujaa vamman tai pitkäaikaisen sairauden hallinnassa. Tutkimuksen tavoitteena oli selvittää sopeutumisvalmennukseen saapuvien aikuisten kuntoutujien elämäntilannetta, sairauskäsityksiä, hallinnan tunnetta, terveyteen liittyvää valtaistumista ja sopeutumisvalmennukseen kohdistuvia odotuksia. Kurssimuotoja oli kolme: syöpää, fibromyalgiaa ja diabetesta sairastavien kurssit. Neljän kuntoutuslaitoksen toteuttamille kursseille osallistui vuosina 2014-15 toteutetun tiedonkeruun aikana 581 kuntoutujaa, joista 377 (65\%) antoi kirjallisen suostumuksen osallistua tutkimukseen ja vastasi alkukyselylomakkeeseen. Kurssiryhmät erosivat sairauskäsitystensä suhteen toisistaan. Kuntoutujien elämäntilanne, sosiaalinen ja institutionaalinen luottamus sekä sairauden rajoitukset olivat yhteydessä hallinnan tunteeseen. Sopeutumisvalmennukseen kohdistuvat odotukset muodostivat neljä ulottuvuutta: palvelutietoja, sairautta ja sen hoitoa koskevia tietoja, psykososiaalista asiantuntijatukea sekä vertaistukea koskevat odotukset. Odotukset vaihtelivat kurssiryhmittäin. Sairauskäsityksiin liittyvät sairauden oireet, huolestuneisuus, tunnereaktiot ja käsitys hoidon vaikutuksista ja omista vaikutusmahdollisuuksista selittivät odotusten vaihtelua. Tietoihin ja psykososiaaliseen asiantuntija-apuun kohdistuvien odotusten todennäköisyyttä lisäsi terveyteen liittyvän valtaistumisen osalta tiedollisen hallinnan vähäisyys, kun taas vertaistukeen liittyvien odotusten todennäköisyyttä lisäsi vahva tiedollinen ja psykososiaalinen hallinta.

\section{Abstract}

Illness perceptions, empowerment and rehabilitation expectations of persons attending psychosocial rehabilitation

Adaptation training is a form of psychosocial rehabilitation that aims to empower the client in coping with his or her illness or disability. The aim of the study was to examine the life situation, sense of mastery, illness perceptions, health-related empowerment and rehabilitation needs and expectations of clients attending adaptation training courses for adults with cancer, fibromyalgia or diabetes. In 2014-15, 581 clients attended these courses in four rehabilitation centers; 377 of them gave their informed consent to participate the study and answered the questionnaire at the beginning of the course. The three groups differed according to their illness perceptions and rehabilitation expectations, but there was also much variance between group members. Life situation, perceived disability, and social and institutional trust were associated with sense of mastery. Rehabilitation expectations were grouped into four main dimensions, i.e., information about services and support, information about the illness and treatment and rehabilitation op- 
tions, psychosocial professional support, and peer support. Illness perceptions, i.e. perceived symptoms, worry, emotional reactions, experienced outcomes of treatment, and perceptions of one's own possibilities to influence the illness were associated with different dimensions. Healthrelated empowerment was also connected with expectations. Expectations for information and professional help were stronger in those with weak informational mastery, whereas expectations for peer support were stronger with those whose informational and psychosocial mastery was better than average.

\section{Kristiina Härkäpää, FT, professori,} kuntoutustiede, Lapin yliopisto

\section{Aila Järvikoski, YTT, professori (emerita), kuntoutustiede, Lapin yliopisto}

Anu Kippola-Pääkkönen, YTM, tutkija, Lapin yliopisto

\section{Marjatta Martin, YTT, yliopistonlehtori, Lapin yliopisto}

Ilona Autti-Rämö, johtava ylilääkäri, tutkimusprofessori, Kansaneläkelaitos

\section{Lähteet}

Aneshensel CS (2015) Sociological inquiry into mental health: The legacy of Leonard I. Pearlin. J Health Soc Behav 56, 166-178.

Arnold LM, Crofford LJ, Mease PJ, Burgess SM, Palmer SC, Abetz L, Martin SA (2008) Patient perspectives on the impact of fibromyalgia. Patiend Educ Couns 73, 1, 114-120.

Asadi-Lari M, Tamburini M, Gray D (2004) Patients' needs, satisfaction, and health-related quality of life: Towards a comprehensive model. Health and Quality of Life Outcomes 2004, 2, 32.

Avison WR, Cairney J (2003) Social structure, stress, and personal control. Teoksessa Zarit SH, Pearlin LI, Schaie KW (toim.) Personal control in social and life course contexts. New York, Springer, 127-164.

Beran D (2015) Needs and needs assessments. A gap in the literature for chronic diseases. SAGE Open 2015, April-June, 1-10.

Broadbent E, Donkin L, Stroh JC (2011) Illness and treatment perceptions are associated with adherence to medications, diet, and exercise in diabetic patients. Diabetes Care 34, 338-340.

Broadbent E, Petrie KJ, Main J, Weiman J (2006) The Brief Illness Perception Questionnaire. J Psychosom Res 60, 631-637.

Corter AL, Findlay M, Broom R, Porter D, Patrie KJ (2013) Beliefs about medicine and illness are associated with fear of cancer recurrence in women taking adjuvant endocrine therapy for breast cancer. Br J Health Psychol 18, 168-181.

Dalgard OS, Mykletun A, Rognerud M, Johansen R, Zahl PH (2007) Education, sense of mastery and mental health: results from a nation wide health monitoring study in Norway. BMC Psychiatry 7, 20-28.

Dunn J, Steginga SK, Rosoman N, Millichap D (2003) A review of peer support in the context of cancer. J Psychosoc Oncol 21, 55-67.

Embuldeniya G, Veinot P, Bell E et al. (2013) The experience and impact of chronic disease peer support interventions: A qualitative synthesis. Patient Education and Counseling 92:3-12.

Gadalla TM (2009) Sense of mastery, social support, and health in elderly Canadians. Journal of Aging and Health 21, 581-595.

Glattacker M, Opitz U, Jäckel WH (2010) Illness representations in women with fibromyalgia. $\mathrm{Br} \mathrm{J}$ Health Psychol 15, 367-387.

Grönlund K, Setälä M (2012) In honest officials we trust: Institutional confidence in Europe. Am Rev Public Adm 42, 523-542.

Hannonen P (2007) Fibromyalgia. Teoksessa Martio J, Karjalainen A, Kauppi M, Kukkurainen ML \& Kyngäs H (toim.) Reuma. Duodecim, Hämeenlinna, 415-428.

Hayes SM, Myhal GC, Thornton JF, Camerlain M, Jamison C, Cytryn KN, Murray S (2010) Fibromyalgia and the therapeutic relationship: Where uncertainty meets attitude. Pain Res Manage 15, 385-391.

Homan-Helenius P (2005) Empowering families of children with asthma through adaptation training. Annales Universitatis Turkuensis, Series D. Turun Yliopisto, Turku.

Hoving JL, van der Meer M, Volkova AY, Frings-Dresen MHW (2010) Illness perceptions and work participation: a systematic review. Int Arch Occup Environ Health 83, 595-605.

Husson 0, Thong MSY, Mois F, Oerlemans S, Kaptein AA, van de Poll-Franse LV (2013) Illness perceptions in cancer survivors: what is the role of information provision? Psycho-Oncology 22, 490-498.

Härkäpää K, Järvikoski A, Gould R (2014) Motivational orientation of people participating in voca- 
tional rehabilitation. J Occup Rehab 24, 658-669.

Järvikoski A, Härkäpää K (2014) Teoreettisia näkökulmia psykososiaaliseen sopeutumiseen ja sopeutumisvalmennukseen. Teoksessa: Streng $\mathrm{H}$ (toim.) Sopeutumisvalmennus: suomalaisen kuntoutuksen oivallus. Raha-automaattiyhdistys, Espoo, 101-147.

Järvikoski A, Härkäpää K, Romakkaniemi M, Nordling E (2016) Koettu työkyky ja hyvinvointitekijät Lapin 40-59-vuotiaassa väestössä. Kuntoutus 39, 2, 6-20.

Kaptein AA, Yamaoka K, Snoei L, van der Kloot WA ym (2013) Illness perceptions and quality of life in Japanese and Dutch women with breast cancer. Journal of Psychosocial Oncology 31, 83-102.

Kaptein AA, Schoones JW, Fischer MJ, Thong MSY, Kruep JR, van der Hoeven KJM (2015) Illness perceptions in women with breast cancer - a systematic literature review. Curr Breast Cancer Rep 7:117-126.

Kersten P, George S, McLellan L, Smith JAE, Mullee MA (2000) Disabled people and professionals differ in their perceptions of rehabilitation needs. Journal of Public Health Medicine 2000, 22, 393-399.

Kessler RC, Andrews G, Mroczek D, Ustun TB, Wittchen H-U (1998) The World Health Organization Composite International Diagnostic Interview Short-Form (CIDI-SF). Int J Methods Psychiatr Res 7, 4, 163-171.

Kippola-Pääkkönen A, Härkäpää K, Järvikoski A, Autti-Rämö I (2016) Sopeutumisvalmennuskursseille osallistuvien lasten vanhempien arvioita hyvinvoinnista, toimintakyvystä ja kurssiodotuksista. Kuntoutus 39, 1, 6-21.

Koren PE, Dechillo N, Friesen BJ (1992) Measuring empowerment in families whose children have emotional disabiltiies - A brief questionnaire. Rehabilitation Psychology 37, 305-321.

Lelorain S, Bonnaud-Antignac A, Florin A (2010) Long term posttraumatic growth after breast cancer: prevalence, predictors and relationships with psychological health. J Clin Psychol Med Settings $17,14-22$.

Lempp HK, Hatch SL, Carville SF, Choy EH (2009) Patients' experiences of living with and receiving treatment for fibromyalgia syndrome: a qualitative study. BMC Musculoskeletal Disorders 10, 124-134.

Leventhal H, Diefenbach M, Levanthal EA (1992a) Illness cognition: using common sense to understand treatment adherence and affect cognition interactions. Cognitive Therapy \&t Research 16, $143-163$.
Leventhal H, Leventhal EA, Contrada RJ (1992b) Selfregulation, health, and behaviour: A perceptual-cognitive approach. Psychology \& Health 13, 717-733.

Markkula R, Järvinen P. Leino-Arjas P, Koskenvuo M, Kalso J, Kaprio J (2009) Clustering of symptoms associated with fibromyalgia in a Finnish Twin Cohort. European Journal of Pain 13, 744-750.

Masterson S, Owen S (2006) Mental health service user's social and individual empowerment: Using theories of power to elucidate far-reaching strategies. Journal of Mental Health 15, 19-34.

Mohseni M, Lindstrom M (2007) Social capital, trust in the health-care system and self-rated health: the role of access to health care in a population-based study. Social science \&t medicine 64, 1373-83.

Moos RH, Holahan CJ (2003) Dispositional and contextual perspectives on coping: Towards an integrative framework. Journal of Clinical Psychology 59, 1387-1403.

Morgan K, Villiers-Tuthill A, Barker M, McGee H (2014) The contribution of illness perception to psychological distress in heart failure patients. BMC Psychology 2014, 2, 50-58.

Nylen M, Tervonen S, Leino E (2009) Hoidonohjauksen ja kuntoutuksen merkitys epilepsiapotilaan kannalta. Duodecim 125, 22, 2543-51.

Nyqvist F, Forsman AK, Cattan M (2013) A comparison of older workers' and retired older people's social capital and sense of mastery. Scand J Public Health 41,792-798.

Park CL (2010) Making sense of the meaning literature: An integrative review of meaning making and its effects on adjustment to stressful life events. Psychological Bulletin 136, 257-301.

Park CL, Edmondson D, Fenster JR, Blank TO (2008) Meaning making and psychological adjustment following cancer: The mediating roles of growth, life meaning, and restored just-world beliefs. Journal of Consulting and Clinical Psychology 76, 863-875.

Pearlin L, Schooler C (1978) The structure of coping. J Health Soc Behavior 19, 2-21.

Pearlin L, Bierman A (2013) Current issues and future directions in research into the stress process. Teoksessa Aneshensel CS, Phelan JC, Bierman A (toim.) Handbook of Sociology of Mental Health, 2. p., Dordrecht, Springer, 325-340.

Perrot S, Choy E, Petersel D, Ginovker A, Kramer E (2012) Survey of physician experiences and perceptions about the diagnosis and treatment of fibromyalgia. BMC Health Services Research 12, 356-363.

Pudrovska T (2010) Cancer and mastery: Do age and 
cohort matter? Soc Sci Med 71, 1285-1291.

Pudrovska T, Schieman S, Pearlin LI, Nguyen K (2005) The sense of mastery as a mediator and moderator in the association between economic hardship and health in later life. J Aging Health 17, 634-660.

Pukkala E, Dyba T, Hakulinen T, Sankila R. Syövän ilmaantuvuus, syöpäpotilaiden ennuste ja syöpäkuolleisuus. www.syöpä.fi

Puumalainen J, Härkäpää K, Järvikoski A (2014) Odotukset, osallisuus ja koetut vaikutukset: Osallistujien kokemuksia vaikeavammaisten lääkinnällisestä kuntoutuksesta. Kuntoutus 37, 4, 5-19.

Rissanen P, Vertio H, Lanning M (2008) Syöpä. Kirjassa: Rissanen P, Kallanranta T, Suikkanen A, toim. Kuntoutus. Duodecim, Helsinki, 121-137.

Sallinen M, Kukkurainen ML, Peltokallio L (2011) Finally heard, believed and accepted - Peer support in the narratives of women with fibromyalgia. Patient education and counseling 85, 126-130.

Schieman S, Turner HA (1998) Age, disability, and the sense of mastery. Journal of Health and Social Behavior 39, 3, 169-186.

Sharpe L, Curran L (2006) Understanding the process of adjustment to illness. Soc Sci Med 62, 1153-1166.

Streng H, toimituskunta (2014) Julistus sopeutumisvalmennuksen puolesta. Teoksessa: Streng $\mathrm{H}$ (toim.) Sopeutumisvalmennus: suomalaisen kuntoutuksen oivallus. Raha-automaattiyhdistys, Espoo, 339-42.

Tang TS, Funnell MM, Gillard M, Nwankwo R, Heisler M (2011) The development of a pilot training program for peer leaders in diabetes: Process and content. Diabetes Education 37, 67-77.

Tigerstedt C, Huhtanen P (2013) Päihtyneiden aiheuttamat häiriöt julkisilla paikoilla. Teoksessa Warpenius K, Holmila M, Tigerstedt C (toim.) Alkoholi- ja päihdehaitat läheisille, muille ihmisille ja yhteiskunnalle. Terveyden ja hyvinvoinnin laitos, Tampere 2013.

Ussher J, Kirsten L, Butow P, Sandoval M (2006) What do cancer support groups provide which other supportive relationships do not? The experience of peer support groups for people with cancer. Soc Sci Med 62, 2565-2576.

Walker JS, Thorne EK, Powers LE, Gaonkar R (2010) Development of a scale to measure the empowerment of youth consumers of mental health services. Journal of Emotional and Behavioral Disorders 18, 51-59.

van Uden-Kraan CF, Drossaert CHC, Taal E, Shaw BR, Seydel ER, van de Laar MAFJ (2008) Empowering processes and outcomes of participation in online support groups for patients with breast cancer, arthritis, or fibromyalgia. Qualitative Health Research 18, 405-417.

Ward MM (2013) Sense of control and self-reported health in a population-based sample of older Americans: Assessment of potential confounding by affect, personality, and social support. Int J Behav Med 20, 140-147.

Weinman J, Petrie KJ, Moss-Morris R, Home R (1996) The Illness Perception Questionnaire: a new method for assessing the cognitive representation of illness. Psychology \& Health 11, 431-445.

Wen K-I, Gustafson DH (2004) Needs assessment for cancer patients and their families. Health and Quality of Life Outcomes 2004, 2, 11.

Vilkkumaa I (2014) Ihminen suhteessa ympäristöönsä. Teoksessa: Streng H (toim.) Sopeutumisvalmennus: suomalaisen kuntoutuksen oivallus. Rahaautomaattiyhdistys, Espoo, 203-225. 